\title{
Corporate Governance in Developing Countries: Finding the Balance between Global Standards and Local Context - The Case of Poland
}

\author{
Jan Jezak
}

\begin{abstract}
The purpose of this paper is to analyse global, mainly Anglo-Saxon and German, experience in the field of corporate governance and then attempt to answer the question to what extent this experience should be used by the developing countries like Poland. In the first part of the paper the author conducts a review of the world literature and presents the most important conclusions from the discussion on the need for changes in both Anglo-Saxon and German corporate governance solutions. In the second part of the paper, the author analyzes the Polish solutions against this background and tries to indicate those areas of Polish corporate governance which require significant changes. The paper ends the recapitulation of the most important conclusions from the discussion.
\end{abstract}

Index Terms-Board of directors, commercial companies code, corporate governance, monistic and dualistic systems, supervisory board, the Polish system of corporate governance.

\section{INTRODUCTION}

Even a brief analysis of corporate governance systems around the world shows the variety of the solutions used and, at the same time, differences between them. These differences apply almost to everything: legal, economic, political, and social systems, the nature and role of corporations in the economy, as well as systems of management and control over corporate operations [1].

The above leads to the conclusion that institutional and structural solutions with regard to corporate governance have an individual nature and are deeply embedded in the economic tradition and corporate culture of a given country. Corporate governance, as yet, does not have a single, widely accepted theoretical base or a commonly accepted paradigm [2]. Thus, each country should develop its own approach and solutions in this field using, of course, experience from other countries or regions. The purpose of this article is to identify directions with regard to improvement of the corporate governance systems currently dominant around the world, and then on this basis to provide an answer to the question: what should be implemented or modified in institutional and structural solutions in this field in developing countries like Poland.

Manuscript received March 2, 2014; June 3, 2014. This work was supported in part by the Polish National Science Centre under Grant N N115 401340.

Jan Jezak is with the Faculty of Management, University of Lodz, Lodz, 90-237 Poland (e-mail: jjezak@uni.lodz.pl).

\section{LITERATURE REVIEW}

Corporate governance has attracted growing attention over the last thirty years, leading to formulated codes of practice, conceptual models and empirical studies over the world. Based on a review of the world literature, corporate governance is defined as the structure and processes between the board of directors (or supervisory board) shareholders, top managers and other stakeholders, and involves the roles of the strategic leadership, and the objectives of assuring accountability and improving performance [3]-[7].

Comparing the Anglo-Saxon and the German systems, which are of greatest interest to us, the first factor that differentiates them is the level of corporate ownership concentration. The Anglo-Saxon solutions are characterized by dispersed ownership, while the German system by ownership concentrated in the hands of several shareholders (blocks of shares or votes). This is the result of the presence or absence of some relevant legal regulations. Certain legal restrictions, e.g. the American investment limits with regard to holdings, shape specific ownership structures in companies. A lack of such limits, e.g. in the case of German banks, leads to their dominance in the ownership structures of local companies, and, indirectly, to a high degree of concentration of ownership in these companies. However, it is necessary to point out that concentration of corporate ownership is not an unambiguously negative phenomenon as there is no strong empirical evidence that companies with concentrated ownership structures, e.g. German, French, or Japanese, are less effective than those with dispersed shareholder structures, e.g. American, British or Australian.

The second factor differentiating the Anglo-Saxon system from the German one is the structure of shareholders. Individual shareholders are in the minority in all regions of the world. As a result of the process of institutionalisation of corporate ownership, which has been progressing since the mid-1970s, institutions such as pension funds and investment funds have come to be the holders of the largest blocks of shares in Anglo-Saxon companies. On the other hand, in German companies this role is performed by banks, insurance companies and holdings companies. In continental Europe and Japan the institutionalization of ownership is additionally reinforced by so-called mutual or cross ownership, which is supposed to expand and strengthen influences of holdings as shareholders. The institutionalisation of shareholder structure should be regarded as one of the most important features of contemporary corporate governance. It brings about important changes not only in the ownership structures of 
companies but also in the systems of supervising and managing their operations. In the end of twenties century these changes were significant enough to gain a special name: investor capitalism.

Any discussion of the advantages and disadvantages of particular systems of corporate governance must necessarily address the monistic and dualistic of governance. The monistic, or one-tier, system practiced in Anglo-Saxon companies concentrates the management and supervisory functions in the hands of one body referred to as the board of directors. The board of directors usually consists of two groups of members, namely those taking an active part in the company's management processes (so-called internal directors) and those performing only supervisory tasks (external directors). Some managerial functions may be delegated to other employees of the company who are not members of the board of directors. Such staff members are usually defined as corporate officers. They, however, do not form a separate managing body. On the other hand, the dualistic, or two-tier, system is popular in the prevailing part of continental Europe, and clearly distinguishes the supervisory function, which is performed by a separate body, known as the supervisory board (German Aufsichtsrat), while the management function is performed by the management board (German Vorstand). Both bodies operate alongside and none of them can issue binding commands to the other. Their mutual impact is, however, quite evident e.g. it is usually the supervisory board that appoints and dismisses the company's management board and determines the remuneration of its members.

The dualistic system, practiced mainly in Germany and Austria, and optionally also in France, is often criticized exactly for this reason, that is, due to the fact that complete knowledge about the company is not guaranteed to the persons performing the supervisory functions. These persons, coming from outside the company and not having exact knowledge about it, cannot effectively monitor and control the operations of the management board or provide advice to it. Supporters of the dualistic system emphasize, however, that persons from outside the company, having their own managerial or office experience, are able to more objectively look at the activities of a given company and, being independent, better represent the interests of the shareholders and others stakeholders. Finally, in Germany, a separate supervisory body is a platform for cooperation between the representatives of the investors and employees (the co-determination principle). On the other hand, there is no doubt that the monistic system has a great advantage in that it provides members of board a full knowledge about what is happening in the company and ensures hands-on monitoring of the situation.

A very convincing proof for lack of this advantage has been provided by the decision-making process in the Daimler-Benz/Chrysler merger. This case shows that the role of the, supervisory board in Daimler-Benz AG was purely perfunctory [8].

The excessively strong position of management boards in German companies, their close connections with suppliers and banks, and, at the same time, the weak position of supervisory boards arouses anxiety among German investors, who are becoming increasingly influential by the year. Similarly, in other countries associations of investors demand greater transparency and improvement in internal control systems as well as effectiveness from corporate management staff. According to some authors, German companies and German management are gradually becoming "Americanized" [9], [10]. This applies in particular to large German companies operating in international markets, such as e.g. Daimler-Benz, Hoechst, Bayer, BASF, Bosch, Siemens, Thyssen-Krupp, and Deutsche Bank. These companies have adapted the American philosophy of managing value for shareholders, with the market price of shares being an important determinant of their effectiveness. They communicate to their investors such important information as the anticipated future profits and dividends. They apply the commonly adopted measures of profitability such as return on equity (ROE) and return on capital (ROC). In addition, they use modern forms of motivating managers (e.g. share options), and send outstanding young managers to do MBA studies in the best American business schools. Finally, these companies take an active part in mergers and takeovers as well as implement the international accounting standards (based on the American concept), and their business language is English. All of these actions result from the presence of the largest German companies in the international capital markets, including the New York Stock Exchange.

The above leads to the conclusion that German corporate governance tries to face up to the challenges related to the processes of globalization of business operations. This openness may give rise to an interesting combination of the American idea of value for shareholders with the German ideas of social dialogue, social balance and corporate social responsibility. Such a combination may become a solution for some developing countries from Central and Eastern Europe.

At this point, to objectively evaluate both systems it needs to be stressed that the American concept of corporate governance is also undergoing a far-reaching metamorphosis. After a series of bankruptcies and corporate abuse at the beginning of the first decade of the 21 st century (Enron, WorldCom, Global Crossing, Tyco International) studies showed many pathological phenomena in American public companies. One of them was excessive concentration of power. At this time in $80 \%$ of American companies included in the S\&P 500 Index, the functions of the chairman of the board of directors and the chief executive officer (CEO) were held by the same person. Also surprising was the scale of the phenomenon of directors sitting on boards in other companies at the same time. An analysis conducted by Bloomberg found that CEOs of the fifty largest American listed companies were members of, on average, three other boards of directors [9].

The aforementioned weaknesses of American corporate practices are nothing new. These inadequacies have been known for years. Investor circles were, however, surprised in terms of the scale of some phenomena, such as, e.g., combining the function of the chairman of the board with that of the CEO, simultaneous membership in the boards of directors of many companies, or the constantly growing 
remunerations of managers, practically without connection with the results of the companies managed by them. In view of the above phenomena, American associations of investors, and especially the influential Council of Institutional Investors, claim that this state of affairs is attributable not only to CEOs, but also to stock analysts, audit and rating companies, as well as persons and institutions supervising the financial markets.

\section{IMPLICATIONS FOR BUILDING A MODERN CONCEPT OF CORPORATE GOVERNANCE}

The above comparison of the two most popular systems of corporate governance proves that none of them is an ideal concept. On the contrary, each of them has many weaknesses or flaws caused by the opportunism of managers, members of supervisory and executive bodies, or the dominant shareholders. These flaws most often occur due to causes of ethical nature. Nevertheless, to prevent them some institutional solutions have been established or improved in all concepts with a view to eliminating harmful behaviour against the company as a separate economic entity, and in particular against its minority shareholders.

It is interesting that the majority of such changes follow the same direction, regardless of the implemented corporate governance model. The most visible changes showing this convergence are the following:

- Strengthening the role of boards of directors (supervisory boards) as strategic partner for the company's management [11]. This is caused by the progressing institutionalization of corporate ownership, and consequently, a return to the traditional, active role of shareholders in companies (investor capitalism). The second factor strengthening the role of the boards is related to sudden bankruptcies and corporate scandals in many countries (the United States, Germany, France, Italy, Great Britain). They attracted the attention of investors and the general public to the monitoring and control functions of the boards as well as their key role in assessing the quality of the company's management. Instead of boards formed by managers, that is, by the people being controlled, it is stressed that the boards need to be treated as an extension of shareholders, or as guardians of the interests of all shareholders, not excluding the minority ones. It is worth emphasizing that reinforcement of the independence of boards and their pro-investor orientation widely discussed not only in Anglo-Saxon countries, but also in Germany. For example, in Germany the boards have so far mostly cared about the interests of major shareholders and employees, but now a growing importance is given to the interests of the minority shareholders. Following this, the quality of financial statements as well as other information related to company operations is improving [10], [12].The most important factor strengthening the role of the boards in the Anglo-Saxon system is independence of the so-called external directors, that is, the group of board members who deal with supervisory activities. In the case of the monistic system, what is mainly at stake is independence from the CEO and other top-level managers. On the other hand, in the dualistic system, the focus is on independence from major shareholders. The advisory company KPMG has carried out a study to clarify the notion of independence. A survey conducted among board members of 213 European companies found that $87 \%$ of the surveyed considered a lack of financial and business connections between board members and management the most important criterion of independence [13].

- An important element of strengthening the position of the boards is separation of the function of the chairman of the board of directors and the CEO. This applies in particular to American companies, as in British companies these two positions have been usually kept separate for many years now. Therefore, the American concept is to some degree getting closer to the over 100-year-old idea present in German corporate governance concerning the separation of the supervisory function from the managerial function in a company.

- A solution strengthening the role of boards and recommended both in monistic and dualistic systems is appointment of committees. These are most often designed for audit, nomination, and remuneration issues, and often also for executive matters (being involved in the preparation of the board's position concerning the key decisions of the company's management) or financial matters (in the case of large international companies running various investment projects and requiring extensive capital commitment). According to the formulated recommendations, audit and remuneration committees should be formed only of independent board members.

- Another postulate formulated both in monistic and dualistic systems is to treat the board of directors and the supervisory board as strategic resources of the company. The board, and in particular its appropriately appointed external members, may be the source of specialist knowledge as well as rich business experience as well as a source of valuable contacts. A concept of the supervisory board which effectively cooperates with and supports the board of directors, especially with regard to strategic decision-making, involves the so-called resource-based trend in company management. This also means seeking a balance between, on the one hand, monitoring and supervision over the management board's work and, on the other hand, cooperation with and advising the management board.

- Finally, an extremely important factor common to all systems of corporate governance is the formulation of codes of good corporate practices. The initiative started in Great Britain in the early 1990s as a result of the well-known report by A. Cadbury. It has become a platform for building a transnational standard with regard to corporate governance, among other things, in terms of systems of informing investors, principles of protecting the capital minority, organizing general meetings of shareholders, as well as the work of supervisory and management boards.

The aforementioned changes in the systems of corporate governance show that we are witnessing a slow convergence 
of these systems. Of course, these processes are occurring gradually and at least in the nearest future the specific nature of national corporate governance system will be preserved, an example here being the German and Japanese concepts. Just as J. Lorsch has envisaged, with the deepening globalization of business operations, corporations themselves, their governance systems, and their management and control practices are becoming global [14], [15].

Summing up, it has to be said that the process of convergence of various corporate governance concepts, which is observed around the world, is increasingly evolving in the direction of the Anglo-Saxon system. This phenomenon is also visible in continental Europe, where the German system is preserved in the formal-legal sense only in a few western countries (Germany, Austria, the German-speaking part of Switzerland). It must be added that this concept is also changing, gradually absorbing some elements of the Anglo-Saxon solutions.

\section{The Polish CORPorate Governance SYSTEM-DiRECTIONS OF CHANGES}

The existing principles of functioning of joint stock companies in Poland are based on the German concept and were written down in the form of a code in the mid-1930s. Pursuant to the essence of the German system, they stipulate the separation of managerial functions from supervisory ones in running a company. Thus, the management board independently manages the current operations of a company and represents it outside. The competences of the management board include all rights which are not reserved for other company bodies under the provisions of the Polish Commercial Companies Code [16]. Members of the management board are required to ensure the proper operation of the company, in accordance with its purpose and object of operations specified in its articles of association, and at the same time demonstrate due diligence - to an extent higher than generally required. This diligence should arise from the professional nature of operations of the company's administrator - Article 483, § 2 of the Polish Commercial Companies Code [17].

Along with the management board, a body which is obligatorily appointed in Polish companies is the supervisory board. The main task of this body is to carry out permanent supervision over the company's business in all fields, including supervision over the company (companies) run by the company.

It is extremely important to stress that, in accordance with the Article 375 of the Polish Commercial Companies Code, the supervisory board is not authorized to issue to the management board any binding commands concerning company matters. Therefore, the rights of the management board and the supervisory board are clearly separated, emphasizing that the management board works within the scope of its rights independently and is not subordinate to the supervisory board [17].

In our opinion, the decision included in Article 375 of the Commercial Companies Code is an expression of excessive faith in the power of managers, which E. Berglöf and E. L. von Thadden warn against [18]. This deepens the dualistic character of Polish corporate governance, and, as a consequence, reduces mutual trust as well as hinders cooperation between a company's management board and supervisory board. Furthermore, this solution is not in line with the spirit of the latest tendencies in reforming corporate governance in the world, in particular in the so-called post-Enron age. The answer to these phenomena is to strengthen the position of management boards and supervisory boards, extending their activity not only with regard to the control function, but also the advisory function - in accordance with the common belief that the board is a strategic resource of the company that should be used by managers in strategic management processes.

It is also necessary to remember that supervisory boards in Polish companies have a slightly weaker formal and legal position than those in German companies, operating under the same system. In the German commercial law, like in the Polish case, supervisory boards jointly approve some specific actions of management boards. In German companies, the list of these activities is, however, generally quite long. For instance, it applies to important investment projects, purchasing or disposing of real estate, taking loans above a specified amount, granting loans or credit guarantees to other entities, undertaking restructuring projects on a large scale, opening or closing representative offices or plants, undertaking a new type of activity, purchasing or selling shares, employing or dismissing high-ranking employees, and granting powers of attorney [19]. A list of decisions subject to approval may be even longer and is determined by the company's articles of association or by the board itself in the case of a vital interest of the company (management boards may not appeal such decisions of supervisory bodies to general meetings of shareholders). In contrast, Polish supervisory boards are unable to extend their control rights [16] as this type of change would each time require a corresponding change in the articles of association, which belongs to the competences of the general meeting of shareholders. Furthermore, when the supervisory board of a Polish company refuses to perform a given activity listed in the articles of association, the management board may apply for approval to the general meeting of shareholders [16]. It is beyond doubt that these solutions put Polish supervisory boards in a significantly worse position than those in German companies.

\section{CONCLUSIONS AND DIRECTIONS FOR FURTHER DISCUSSION}

The selected areas of Polish corporate governance presented above are obviously not exhaustive in view of the entire problem. If one needs to adopt a more holistic approach to this subject [20], one should take into account the following elements: trade in securities, accounting and the principles of preparing and publishing financial statements, as well as external and internal audit. However, the adopted system of corporate governance has a fundamental importance for the business effectiveness of companies. The dualistic system - which is still in existence in the Polish Commercial Companies Code - is clearly losing some of its importance not only around the world, but also in continental 
Europe. A convergence of the monistic and dualistic systems that has been visible in Europe for some years now as well as the evolution of the dualistic system in Germany should become an impulse for departing from the existing, conservative approach to the separation of managerial and supervisory functions in the Polish commercial law.

After all, one cannot ignore the fact that the monistic system is the absolutely dominant solution in the world and that it is clearly associated with the process of globalization of the world's economy. In addition, some major countries in continental Europe are withdrawing, or have already withdrawn, from the dualistic system (e.g. the Nordic countries), while others, like e.g. France, have granted companies the right to choose a governance system. One of the intentions of the European Commission is to prepare a directive obligating the member states to allow public companies to make such a choice. Therefore, the question arises as to the point of further preserving the separation between managerial and supervisory functions, since more than a century of practicing this system has demonstrated no superiority of the dualistic system over the monistic one. Furthermore, this system seems to create substantial dissatisfaction even in Germany. In any case, the reform of corporate governance in Poland and other Central or Eastern European countries should become the subject of a major discussion among economists, lawyers, and politicians [21].

\section{REFERENCES}

[1] L. Horn, "Corporate Governance in Crisis? The Politics of EU Corporate Governance Regulation," European Law Journal, vol. 18 no. 1, pp. 83-107, January 2012.

[2] B. Tricker, Corporate Governance Principles, Policies and Practices, Oxford-New York: Oxford University Press, 2009, pp. 233-236.

[3] Cadbury Committee, "The Report of the Cadbury Committee on the Financial Aspects of Corporate Governance: The Cod of Best Practise, Accountancy," UK, January 1993.

[4] T. Donaldson and E. L. Preston, "The stakeholder theory of the corporation: Concepts, evidence and implications," Academy of Management Review, vol. 20, no. 1, pp. 65-91, 1995.

[5] C.-K. Ho, Corporate Governance and Corporate Competiveness: An International Analysis, vol. 13, no. 2, pp. 211-253, March 2005.

[6] OECD. (1999). Principles of Corporate Governance. Paris: OECD. [Online]. Available: http://wwwoecd.org

[7] A. Shleifer and R. W. Vishny, "A survey of Corporate Governance," The Journal of Finance, vol. 52, no. 2, pp. 737-783, June 1997.

[8] F. Neubauer, V. Steuer, and G. Rädler, "The daimler merger: The involvement of the boards," Corporate Governance: An International Review, vol. 8, no. 4, pp. 375-387, October 2000.
[9] E. H. Schlie and M. Warner, "The Americanization" of German management," Journal of General Management, vol. 25, no. 3, pp. 33-49, Spring 2000.

[10] A. Börsch, "How international competition reinforces corporate governance and product market strategies: The case of bosch," German Politics, vol. 14, no. 1, pp. 33-50, March 2005.

[11] P. Stiles and B. Taylor, Boards at Work. How Directors View their Roles and Responsibilities, Oxford-New York: Oxford University Press, 2002, pp. 31-59.

[12] P. Witt, Corporate Governance im Wandel, Zeitschrift Führung Organisation, no. 3, pp. 159-163, 2000.

[13] Corporate Governance in Europe. (February 2001, 2002). KPMG International. [Online]. Available: http://www.surveys.kpmg.com/aci/docs/Euro_CorpGov.pdf

[14] J. Lorsch, "Corporate governance," in Concise International Encyclopaedia of Business and Management, M. Warner, Ed. Boston-London: International Thomson Business Press, 1997, pp. 96-106.

[15] P. Zumbausen, "Neither public nor private, national, nor international," Journal of Law and Society, vol. 38 no. 1, pp. 50-75, March 2011.

[16] Act of 15 September 2000 - The Polish Comercial Companies Code, Dziennik Ustaw 2000, no. 94, item 1037; Dziennik Ustaw 2003, no. 49 , item 408, articles: 368, 375, 378, 382-384, 395 and 399

[17] S. Sołtysiński, A. Szajkowski, A. Szumański, and J. Szwaja, Kodeks spótek handlowych, Komentarz, [The Polish Commercial Code. Commentary], vol. II, Warszawa: Wydawnictwo C. H. Beck, 2008, pp. 753-754.

[18] E. Berglöf and E. L. von Thadden, The Changing Corporate Governance Paradigm: Implications for Transition and Developing Countries, Manuscript, Stokholm, SITE, Sweden: Stockholm School of Economics and CEPR, wp. no. 263, 1999.

[19] C. Striebeck, Reform des Aktiesrechts durch die Strukturrichtlinie der Europäischen Gemeinschaften, Peter Lang Verlag, Frankfurt am Main, 1992, pp. 31-59.

[20] P. Hardi and K. Buti, "Corporate governance variables: Lessons from a holistic approach to central-eastern Europe practice," Corporate Governance, vol. 12, no. 1, pp. 101-117, 2012.

[21] J. Franek and M. Hučka, "Assessment methods of corporate governance systems: Factors, indicators and measures," in Proc. 8th European Conference on Management Leadership and Governance, Pafos, 2012, pp. 481-489.

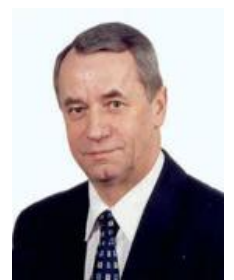

Jan Jezak got his $\mathrm{PhD}$ degree in economics, habilitation in management. He is a professor at the University of Lodz, Central Poland. He has authored or co-authored over 180 publications, mainly in the fields of strategic management and corporate governance. In his academic career he has lectured at the University of Pittsburgh, DePaul University in Chicago, the European University Viadrina Frankfurt (Oder). Since 1994 he is serving on boards of directors of the Polish public companies. He was, among others, the chairman of the board of the First National Fund, Fund. 1 from 1994 to 2002. 